\title{
PENGEMBANGAN MEDIA PERMAINAN DAKON UNTUK MENINGKATKAN KEMAMPUAN BERHITUNG ANAK
}

\author{
Desi Mulyani ${ }^{1}$, Nika Cahyati ${ }^{2}$, Aulia Rahma ${ }^{3}$ \\ ${ }^{1,2}$ STKIP Muhammadiyah Kuningan, Indonesia \\ ${ }^{3}$ Institut Agama Islam Negeri Metro, Indonesia \\ desimulyani477@gmail.com
}

\begin{abstract}
Abstrack
This study aims to develop play media that can develop numeracy skill of children age 4-5 years, as well as determine the effectiveness of these media. This research method uses the Brog \& Gall research and development method which is limited to 6 stage, namely research and data collection, planning, product draft development, initial field trials, revision of trial result, and field implementation trials. Based on the research results, the results of the development of children's numercy skills using dakon media increased by 125, from an initial average value of 62,5 to 187,5. In the t test results, the posttest value of the control class and the experimental class obtained a sig value (2 tailed) of 000. The sig value (2 tailed) of $000<0,05$. So according to the basis of decision making in the t test, it can be concluded that Ho is rejected and Ha is accepted, which means that there is a significant difference, which means that there are differences in the numeracy depelopment of children who do not use the dakon game media with the depelopment of counting children using the dakon game media.
\end{abstract}

Keywords : dakon game; ability; children's numeracy skills

\begin{abstract}
Abstrak
Penelitian ini bertujuan untuk mengembangkan media permainan yang dapat mengembangkan kemampuan berhitung anak usia 4-5 tahun sebanyak 150 anak melalui teknik rundom sampling, serta mengetahui keefektifan dari media tersebut. Metode penelitian ini menggunakan metode penelitian dan pengembangan Borg \& Gall yang dibatasi dengan 6 tahap yaitu penelitian dan pengumpulan data, perencanaan, pengembangan draf produk, uji coba lapangan awal, revisi hasil uji coba, dan uji coba pelaksanaan lapangan. Berdasarkan hasil penelitian hasil perkembangan kemampuan berhitung anak dengan menggunakan media dakon meningkatkan sebesar 125, dari nilai rata-rata awal 62,5 menjadi 187,5. Pada hasil uji t nilai postest kelas kontrol dan kelas eksperimen diperoleh nilai sig ( 2 tailed) sebesar 000. Nilai sig ( 2 tailed) sebesar $000<0,05$. Maka sesuai dasar pengambilan keputusan dalam uji t dapat disimpulkan bahwa Ho di tolak da Ha di terima yang artinya terdapat perbedaan secara signifikan, yang artinya terdapat perbedaan perkembangan berhitung anak yang tidak menggunakan media permainan dakon dengan perkembangan berhitung anak yang menggunakan media permainan dakon.
\end{abstract}

Kata kunci: permainan dakon; kemampuan; berhitung anak 


\section{PENDAHULUAN}

Anak usia dini merupakan individu yang unik dan memiliki karakteristik tersendiri yang sesuai dengan tahapan usianya. Masa usia dini merupakan masa keemasan (Golden Age) yang pada usia ini stimulasi seluruh aspek perkembangan berperan penting (Wijaya Kuswanto \& Dinda Pratiwi, 2020). Salah satu aspek yang harus dikembangkan oleh anak yaitu perkembangan kognitif. Kognitif sangat penting dikembangkan karena agar anak dapat melakukan eksplorasi terhadap dunia sekitar melalui panca inderanya. Pada konsep banyak dan sedikit anak akan dikenalkan pada kegiatan berhitung sederhana dilakukan anak usia dini pada usia 4-5 tahun adalah membilang, mengurutkan, menjumlahkan dan mengurangi angka secara sederhana. Berhitung permulaan anak harus melalui beberapa tahapan yaitu mampu mengenal angka, menyebutkan angka, dan mengurutkan angka dan akhirnya anak mampu melakukan berhitung permulaan secara benar. Berdasarkan Pengamatan di lapangan bahwa masih banyak sekolah yang masih menggunakan LKA dalam memberikan pembelajran pada anak, seharusnya dalam melakukan pembelajaran kepada anak harus menggunakan media dan benda yang konkret, agar pembelajaran anak merasa senang dan tidak bosan. Permainan dakon merupakan permainan papan tradisional yang cukup populer pada zaman dulu. Dakon biasa dimainkan saat senggang secara lesehan di teras rumah atau di bawah pohon. Namun sayangnya, permainan tradisional dakon sudah mulai dilupakan dan jarang dijumpai sekarang ini. Berdasarkan hasil survey, hal ini dikarenakan peralatan permainan yang besar dan repot disiapkan. Selain itu, permainan tradisional dakon dianggap membosankan oleh beberapa responden karena tidak ada reward (Yenti, 2015). Pada pembelajaran guru belum sepenuhnya memfasilitasi anak dengan media, media pembelajaran yang dibuat oleh guru ternyata lebih efektif dibandingkan media yang dibuat oleh tukang, penyebabnya adalah guru mengetahui secara langsung proses pembelajaran sehingga media yang dibuat sesuai dengan kebutuhan anak (Putri Sarasati \& Cahyati, 2020). Hal ini menunjukan bahwa perlunya sebuah inovasi atau rancangan media pembelajaran yang dapat mningkatkan kemaampuan anak, media yang diguanakan tidak hanya dapat meningkatkan satu aspek perkembangan, naum semua aspek perkembangan anak.

Berdasarkan hasil penelitian (Cahyati, 2018) bahwa media dapat meningkatkan kemampuan berhitung anak dengan cara yang menyenangkan. Berdasarkan permasalahan bahwa permainan merupakan suatu alat atau sesuatu kegiatan yang menimbulkan keasyikan dan kesenangan yang dilakukan secara sukarela tanpa paksaan dan rasa tanggung jawab, dan tanpa mempertimbangkan hasil akhir yang dicapai. Permainan tradisional daerah juga memiliki 
potensi besar untuk dimanfaatkan dalam pembelajaran, pembelajaran di sekolah diharapkan tidak hanya bersifat teoritik tetapi juga dapat mengenalkan media pembelajaran dengan menggunakan permainan tradisonal, karena permainan tradisional sudah hampir punah atau tidak selalu digunakan jadi permainan tradisional juga bisa dijadikan sarana pengetahuan bagi anak dalam memberikan pembelajran bermakna, salah satunya permainan congklak atau dakon. Dalam penelitian ini, dakon merupakan salah satu media pembelajaran. Menurut Kurniati (2006, hlm.123) bahwa permainan tradisional dakon merupakan permainan yang menitikberatkan pada penguasaan berhitung. Permainan ini memiliki beberapa peranan, diantaranya adalah untuk melatih keterampilan berhitung anak dan motorik halus. Berdasarkan uraian diatas maka penelitian yaitu untuk mengembangkan media permainan dakon serta keefektifannya. Permainan dakon merupaakan solusi bagi pendidikan anak usia dini, karenaa media permainan dakon tidak hanya memberikan pemahaman satu aspek saja, nnnamun semua aspek perkembangan anak dapat terlihat. Serta permaainan dakon merupakan permainan tradisional, maka dengan menggunakan media ini adalah upaya lembaga mengenalkan budaya pada anak, upaya lembaga untuk memperkenalkaan permainan tradisional, sehingga anak dapat menghargai warisan leluhurnya. Pengembangan media permainan dakon sebagai upaya untuk memenuhi tantangan zaman, karena memberikan kebaruan dalam permainan dakon.

Permainan media dakon merupakan media yang unik bagi anak, sebagai upaya pengembangan media dakon sebelumnya, media dakon yang dibuat melihat berbagai sisi, diantaranya dengan memperbaharui bentuk dakon dari semuala hanya berpentuk lonjong, namun di kembangkan kembali dengan berbentuk ikan, sehingga dapat menarik minat dan minat belajar anak, dan akan meningkatkan kemampuan kognitif anak, karena anak pada dasarnya anak memiliki daya konsentrasi yang rendah, sehingga sangat penting sekali untuk menyajikan media yang unik yang dapat meningkatkan daya konsentrasi anak, salah satunya dengan menggunakan media yang menarik bagi anak. Kemudian media dakon yang dikembangkan itu menggunakan biji-bijian sehingga secara tidak langsung anak anak dapat mengenal biji-bijian tersebut sebagi upaya pengenalan sumber belajar yang berasal dari lingkungan. Permainan Dakon merupakan permainan tradisional yang dapat meningkatkan kemampuan berhitung, karena Permainan Dakon dapat membantu dan mempermudah anak dalam memahami konsep berhitung matematika sekaligus dapat menyenangkan anak karena mengandung unsur permainan. Permainan bagi anak merupakan sesuatu hal yang menarik dan dapat meningkatkan daya konsentrasi anak. 


\section{METODE PENELITIAN}

Penelitian ini merupakan jenis penelitian dan pengembangan atau Research and Development (R\&D). Populasi dalam penelitian ini adalah anak RA usia 4-5 tahun se Kabupaten Kuningan, sampel dalam penelitian ini adalah RA Al hidayah Cikadu, RA Bani Utsman Darma dan RA Dewi Sartika IV. Alur Langkah-langkah Pengembangan tipe Borg\&Gall yang telah disederhanakan (2003:572). Peneliti melakukan penelitian dan pengembangan media permainan dakon untuk perkembangan berhitung anak. Tingkat kelayakan Penggunaan Permainan dakon pada kemampuan berhitung anak usia Dini ini diketahui melalui validasi oleh ahli materi, validasi oleh ahli media, validasi oleh guru dan uji coba penggunaan oleh anak, jenis data dalam penelitian ini adalah data kualitatif dan kuantitatif. langkah-langkah yang harus ditempuh dalam penelitian dan pengembangan, antara lain: (a) studi pendahuluan, (b) perencanaan, (c) pengembangan model hipotetik, (d) penelaahan model hipotetik, (e) revisi, (f) uji coba terbatas, (g) revisi hasil uji coba, (h) uji coba lebih luas, (i) revisi model akhir, dan (j) diseminasi dan sosialisasi.

\section{HASIL DAN PEMBAHASAN}

\section{Hasil Penelitian}

Berdasarkan studi pendahuluan bahwa penggunaan media di lembaga PAUD masih jarang digunakan, di lembaga PAUD pada umumnya pembelajaran masih bersifat konvensional atau bersipat satu arah, penggunaan media masih belum digunakan daalam pembelajaran, serta penggunaan media lokal masih sangat jarang digunakan, karena dianggap kuno dan tidak modern. Perencanaan produk yang dikembangkan berupa media visual yaitu media permainan dakon untuk kemampuan berhitung anak. Media permainan dakon merupakan hasil modifikasi dari permainan congklak. Media permaianan dakon dirancang untuk menarik minat anak usia 4-5 tahun dalam melatih perkembangan kemampuan berhitung anak. Hasil validasi ahli media di dapat data penilaian untuk indikator kesesuaian dengan karakteristik pembelajaran anak medapat 7 poin, indikator kesesuaian dengan media permainan dakon mendapat skor rata-rata 50 , indikator kessesuaian penggunaan permainan dakon mendapat skor rata-rata 100 , indikator pelaksanaan permainan mendapar skor rata- rata 100. Dari hasil validasi ahli media terdapat lima indikator tersebut dapat dilihat bahwa rata-rata skor yang didapat adalah 87,5. Menurut pedoman konversi data kuantitatif ke dalam data kualitatif skala empat dari sukarjo dalam Nur 
Rohman Muktiani (2008 : 80), skor 87,5 masuk kedalam kategori” baik", Dan mucul hasil validasi dari validator media pengembangan permainan dakon untuk perkembangan berhitung anak layak digunakan.

Desain awal media permaianan dakon untuk kemampuan berhitung anak adalah sesuai dengan gambar1.

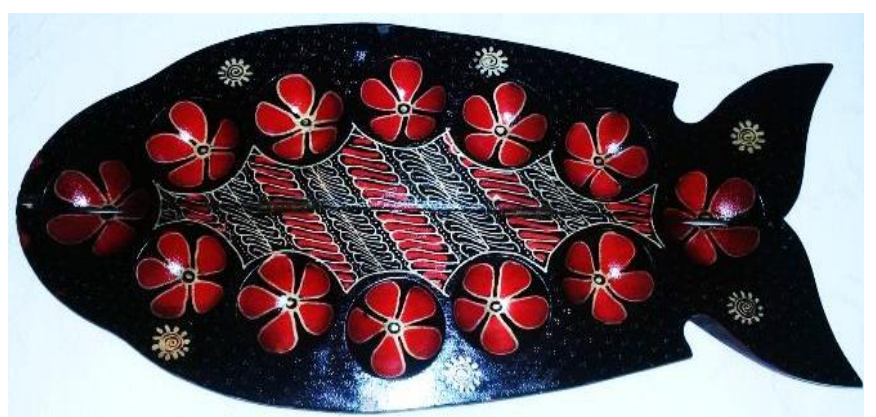

Gambar 1. Dakon Sebelum Validasi

Pada saat pertama validasi media validator enyarankan untuk merubah warna lubang pada media dakon, sehingga dapat menarik perhatian anak karena dakon memiliki warna yang terang, sehingga anak akan lebih antusiuas, maka berdasarkan hasil validsi tersebut peneliti merubah warna media dakon dengan yang lebih terang.

Berdasarkan masukkan dari berbagai pihak maka desain media pengembangan permainan dakon untuk kemampuan berhitung anak berubah menjadi seperti yang terlihat pada gambar 2 .

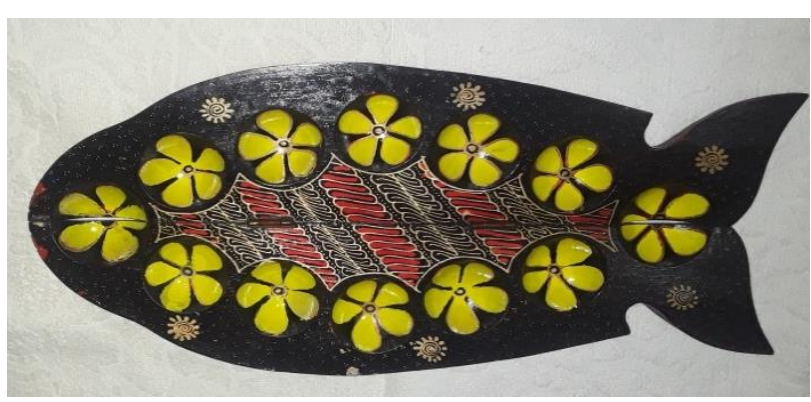

Gambar 2. Dakon Setelah Validasi

Berdasarkan hasil revisi produk dari ahli bahwa media dakon perlu diperbaiki dalam konteks perubahan warna, tujuannya agar dapat terlihat lubang-lubang kecil yang terdapat dalam dakon, sehingga memudahkan anak untuk melihat dan menyimpan biji kedalam lubang 
tersebut. Dengan memili warna yang lebih terang maka media permainan dakon terlihat lebih cerah, sehingga dapat menrik perhatian anak untuk memainkannya atau menggunakannya, dan dengan ketertarikan ini, anak akan mampu meningkatkan kemampuan kognitifnya atau kemampuan berhitungnya, karena awalnya anak merasa tertarik terlebih dahulu, kemudian anak berminat untuk memainkannya sehingga anak ikut serta dalam melakukan permainan dakon ini.

Data penelitian ini terdiri dari data hasil pretest dan posttest kelas kontrol serta data hasil pretest dan postest kelas eksperimen. Data penelitian kelas kontrol dari peserta didik TK Alhidayah berjumlah 5 orang. Berdasarkan data penelitian yang telah dilakukan, nilai tertinggi yang diperoleh pada pretest adalah 3,2 dan posttest adalah 6,4 , nilai terendah yang diperoleh dari pretest adalah 2 dan posttest adalah 6.

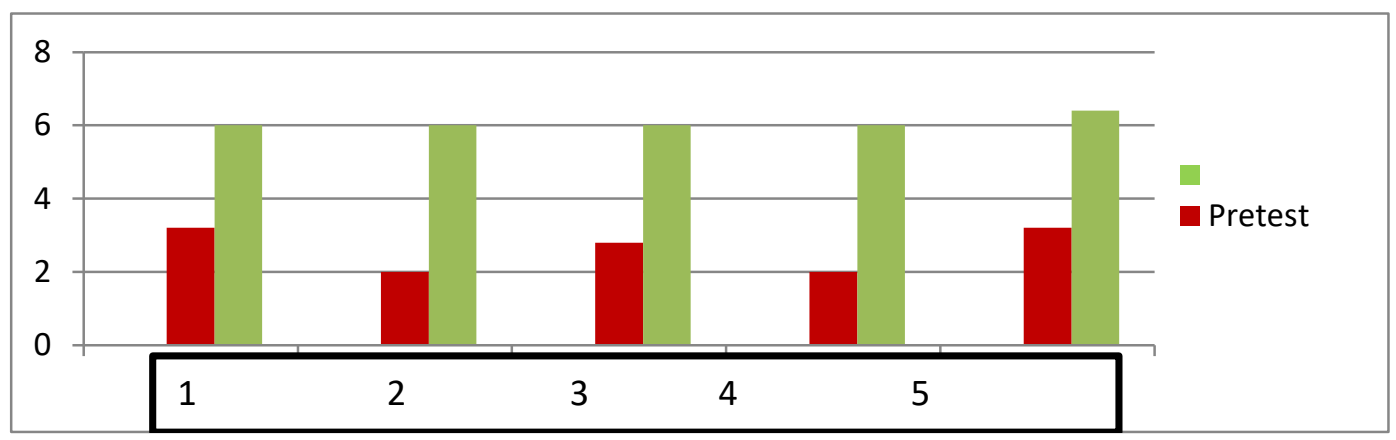

Gambar 1. perbandingan nilai pretest dan postest kelas kontrol.

Untuk menentukan hasil dari penelitian yang dilakukan, maka diperlukan analisis data hasil penelitian. Langkah analisis data yang akan dilakukan terdiri dari uji normalitas, uji homogenitas, dan uji t. Uji normalitas dilakukan untuk menguji apakah persebaran data pretest dan posttest normal atau tidak normal. Berdasarkan hasil uji normalitas pada nilai pretest didapatkan One Sample Test Komolgrove -Smirnov Test dengan sig 0,934 karena sig 0,934 > 0,05 maka data dinyatakan berdistribusi normal. Berdasarkan hasil uji normalitas pada nilai posttest didapatkan Output One-Sample Kolmogrove-Smirnornov Test dengan sig 0,692, karena sig 0,692>0,05. Uji homogenitas dimaksudkan untuk mengetahui apakah data sampel dari populasi yang bervarian homogen atau tidak (Sudarmanto 2013: 132). Uji homogenitas ini dilakukan dengan bantuan program SPSS 21. Hasil uji homogenitas pada nilai pretest kelas kontrol dan eksperimen diperoleh nilai signifikan 0,44, hasil uji homogenitas pada nilai posttest kelas kontrol dan eksperimen diperoleh nilai signifikan 900. Dari penjelasan tersebut maka dapat diketahui bahwa nilai signifikan lebih besar dari 0,05, jadi dapat disimpulkan bahwa 
populasi memiliki varian yang homogen atau tidak data berasal dari populasi dengan varian yang sama.

Uji t ini dilakukan dengan bantuan program SPSS 21. Karena berdasarkan uji normalitas data berdistribusi normal dan uji homogenitas data bersifat homogen maka uji t dilakukan dengan menggunakan statistik parametrik independent simple t-test. Langkah pertama melakukan uji t terhadap nilai pretest dan posttest kelas kontrol dan kelas eksperimen. Hasilnya sebagai adalaha, hasil uji t pretest, diperoleh nilai sig (2.tailed) sebesar 157. Nilai sig. (2.tailed) sebesar, 157>0,05 maka sesuai dasar pengambilan keputusan dalam uji t dapat disimpulkan bahwa Ho diterima dan Ha ditolak, yang artinya tidak terdapat perbedaan secara signifikan anatara hasil pretest kelas kontrol dengan hasil pretest kelas eksperimen. Langkah selanjutnya yaitu uji t tehadap nilai postest kelas kontrol dan kelas eksperimen. Hasil uji t posttest diperoleh nilai sig. ( 2 tailed) sebesar $000<0,05$. Nilai sig. $(2$ tailed) sebesar $000<0,05$ maka sesuai dasar pengambilan keputusan dalam uji t dapat disimpulkan bahwa Ho ditolak dan Ha diterima, yang artinya terdapat perbedaan secara signifikan anatara hasil posttest kelas kontrol dengan posttest kelas eksperimen. Sehingga dapat disimpulkan bahwa terdapat perbedaan perkembangan berhitung anak yang tidak menggunakan media permainan dakon dengan perkembangan berhitung anak yang menggunakan media permainan dakon.

\section{Pembahasan}

Pengembangan media permainan dakon untuk kemampuan berhitung anak usia 405 tahun ini diawali dengan penelitian dan pengumpulan data (research and information collecting) yang meliputi pengukuran kebutuhan, studi literatur, penelitian dalam skala kecil, dan pertimbangan-pertimbangan dari segi nilai. Tahap kedua yaitu menyusun rencana penelitian, meliputi kemampuan-kemampuan yang diperlukan dalam pelaksanaan penelitian, atau langkah-langkah penelitian dan kemungkinan dalam lingkup terbatas. Tahap ketiga pengembangan draf prodak (develop preliminary from of product) meliputi rancangan prodak, desain dan pengumpulan bahan yang akan digunakan. Tahap keempat uji coba lapangan (preliminary field testing). Uji coba lapangan dilakukan pada anak usia 4-5 tahun kelompok A di TK Al-hidayah dan TK Tunas Bakti. Tahap terakhir penyempurnaan produk hasil uji coba lapangan (operasional product revision) berdasarkan uji coba lapangan tahap awal. Uji coba lapangan terdiri dari data hasil pretest dan data hasil posttest kelas kontrol serta hasil pretest dan posttest kelas eksperimen. Data penelitian kelas kontrol diambil dari peserta didik 
kelompok A TK Al-hidayah kelas kontrol sebanyak 5 anak. Berdasarkan data penelitian yang telah dilakukan nilai tertinggi yang diperoleh pada pretest adalah 3,2 dan posttest adalah 6,4, nilai terendah yang diperoleh pada pretest adalah 2 dan pada posttest adalah 6 sedangkan ratarata yang di peroleh pada pretest adalah 62,5 dan pada posttest adalah 187,5 . Peningkatan hasil kemampuan berhitung anak tanpa menggunakan media permainan dakon meningkat sebesar 125 , dari nilai rata-rata awal 62,5 menjadi 187,5 .

Data penelitian pada kelas eksperimen diambil dari peserta didik TK-Tunas Bakti sebanyak 10 anak. Berdasarkan data penelitian yang telah dilakukan, nilai tertinggi yang diperoleh pada pretest 1,6 dan pada posttest adalah 3,2, nilai terendah yang diperolah pada pretest 1,1 dan pada posttest 2,8 sedangkan nilai rata-rata yang diperoleh pada pretest adalah 100 dan pada posttest 200, peningkatan hasil perkembangan kemampuan berhitung anak dengan menggunakan media permainan dakon meningkat sebesar 100 dari nilai rata-rata awal 100 menjadi 200. Hasil penelitian dari (Horunisa \& Cahyati, 2020) menunjukan bahwa pengembangan media dapat efektif meningkatkan perkembangan anak, terutama dalam kemampuan berhitung anak.

Permainan merupakan berbagai kegiatan yang sebenarnya dirancang dengan maksud agar anak dapat meningkatkan beberapa kemampuan tertentu berdasarkan pengalaman belajar. Permainan dakon merupakan salah satu permainan tradisional yang dapat digunakan untuk mengatasi permasalahan kemampuan berhitung anak. Hal tersebut dinyatakan pada buku Pedoman Pembinaan Nilai Budaya melalui Permainan Rakyat Daerah Istimewa Yogyakarta (dalam Sulastri, 2012) bahwa permainan tradisional yang dapat melatih keterampilan menghitung dan kecerdasan adalah permainan dakon. Permainan dakon dapat dilaksanakan dengan beberapa tahapan yang terdiri dari permainan bebas, permainan dengan aturan, permainan mencari kesamaan sifat, permainandengan representasi, permainan dengan simbulisasi, dan formalisasi.

Penggunaan media pembelajaran dalam kegiatan belajar mengajar baik pada mata pelajaran matematika atau mata pelajaran lain harus tetap aktif Media Pembelajaran dapat membantu menghadapi kesulitan-kesulitan anak dalam menganalisa setiap pembelajaran yang mereka hadapi. Penggunaan media pembelajaran dalam Matematika dapat meningkatkan hasil belajar anak, sehingga diharapkan pada matapelajaran lain media pembelajaran harus tetap digunakan (Verdawati, 2013). 
Permainan dakon masih jarang digunakan di lembaga PAUD, pada umumnya pembelajaran masih bersifat konfensional, serta media pembelajaran hanya sebatas pajangan lembaga, implementasi yang kurang dalam penggunaan media membuat anak semakin pasif sehingga sebuah inovasi pembelajaran menggunakan media dakon adaalah jawaban bagi lembaga PAUD yang ingin meningkatkan kualitas pembelajaran. PEnggunaan media permainan dakon di lembaga PAUD yaitu dengan memberikan pembelajaran mengenalkan konsep bilangan, anak belajar mengenal jumlah angka dengan berhitung langsung, serta anak mencoba langsung membagi-bagi kkelereng/biji kedaalam dakon secara teliti, sehingga anak belajar untuk meningkatkan konsentrasinya, serta anak belajar untuk bersikap sportif, akrena permainan dakon ini tidak hanya dimainkan secara mandiri, namun terdapat lawan main, sehingga anak dapat menenrima kekalahan dan kemenangan. Media permainan dakon juga membantu anak untuk bisa saling tidak berebutan, karena permainan ini mengandaalkan ketelitian, sehingga tidak dapat dimainkan dengan berebut. Media permainan dakon yang digunakan menarik minat aanak, penyebabnya adalah media yang digunakan sngat unik, serta biji atau kelereng nya yang digunakan juga bertekstrur, sehingga anak dapat mengenal konsep kasar dan halus, sangat baanyak sekali manfaat media permainan dakon untuk perkembangan anak, tidak hanya pada kognitif namun juga aspek lain.

Hasil penelitian tersebut sesuai dengan penelitian sebelumnya yang dilakukan oleh Supiyatun (2019), bahwa pengembangan media permainan dakon yang dilakukan oleh (supiyatun) bahwa media permainan dakon untuk perkembangan berhitung anak layak dan efektif meningkatkan kemampuan berhitung anak usia 4-5 tahun. Untuk mengetahui keefektifan media yang telah dikembangkan dilakukan uji t. Pada hasil uji t nilai pretest kelas kontrol dan kelas eksperimen diperoleh nilai sig.(2 tailed) sebesar $157>0,05$, maka sesuai dasar pengambilan keputusan dalam uji t dapat disimpulkan bahwa Ho diterima dan Ha ditolak, yang artinya tidak terdapat perbedaan signifikan antara hasil pretest kelas kontrol dengan hasil pretest kelas eksperimen.

Pada hasil uji t posttest kelas kontrol dan kelas eksperimen diperoleh nilai sig.(2 tailed) sebesar 000. nilai sig ( 2 tailed) sebesar $000<0,05$ maka sesuai dasar pengambilan keputusan dalam uji t dapat disimpulkan bahwa Ho ditolak dan Ha diterima, yang artinya terdapat perbedaan yang signifikan antara hasil posttest kelas kontrol dengan posttest kelas eksperimen. Artinya media permainan dakon untuk kemampuan berhitung anak atau congklak membantu meningkatkan kemampuan berhitung anak. Hal ini sesuai dengan penelitian yang telah 
dilakukan oleh Yeni Sri Wuryastuti bahwa pernainan congklak berpengaruh terhadap kemampuan berhitung permulaan anak usia 4-5 tahun. Sesuai dengan hasil penelitian Supiyatun (2019) bahwa media permainan dakon untuk perkembangan berhitung anak layak dan efektif meningkatkan kemampuan berhitung anak usia 4-5 tahun. Media permainan dakon dapat dilakukan dengan kegiatan bercerita, agar anak dapat lebih berkonsentrasi dalam pembelajaran, karena begitu banyak manfaat kegiatan bercerita, bukan hanya manfaat terhadapt bahasa, namun juga untuk perkembangan sosial emosional anak (Haerudin, 2018).

Maka dapat disimpulkan bahwa media permainan dakon layak dan efektif untuk meningkatkan kemampuan berhitung anak usia 4-5 tahun.

Permainan congklak memiliki beberapa manfaat yaitu untuk melatih mengatur strategi, bersikap sportif, bersikap jujur, dan untuk melepaskan penat(Prima Nataliya, 2011). Hal ini sesuai dengan hasil penelitian, bahwa dakon dapat membantu meningkatkan kualitas pembelajaran, berbagai penelitian menunjukan hal tersebut, maka pemnggunaan media dakon adalah hal yang tepat untuk meningkatkan kemampuan berhitung anak.

Permainan media dakon bukan hanya meningkatkan kemampuan berhitung anak, namun anak juga dapat mengenal budayanya sendiri melalui permainan dakon, karena dakon merupakan permainan tradisional yang layak dikembangkan guna agar anak mengenal budayanya sendiri. (Uniati, 2019). Kemampuan berhitung dapat mulai diajarkan sejak usia dini sebab anak-anak di usia ini merupakan periode yang peka terhadap rangsangan yang diterima dari lingkungan. Rasa ingin tahu anak yang tinggi akan tersalurkan apabila mendapat stimulasi atau motivasi yang sesuai dengan tugas perkembangannya. Tujuan dari pembelajaran berhitung pada anak usia dini agar anak dapat berpikir logis dan sistematis sejak dini, dapat menyesuaikan diri dalam kehidupan masyarakat, memiliki ketelitian dan konsentrasi tinggi, memiliki pemahaman konsep ruang dan waktu serta memiliki kreativitas dan imajinasi dalam menerapkan sesuatu. Permainan dakon ini dapat meningkatkan kemampuan berhitung anak, penyebabnya adalah dakon yang biasa digunakan hanya memiliki bentuk oval, kaku dan tidak memiliki warna yang menarik, namun setelah dikembangkan media dakon ini memiliki warna dan gambar yang terang serta memiliki bentuk yang unik yaitu bentuk ikan, karena semua anak menyukai binatang-binatang. Kemudian terdapat biji-bijian yang digunakan untuk permainan dakon, sebagai upaya memperkenalkan ke anak mengenai sumber belajar dari lingkungan sekitar, dan media dakon yang dikembangkan juga terbuat dari kayu yang berada dari lingkungan sekitar anak, sehingga dapat memperkenalkan permainan tradisional sekaligus 
memperkenalkan alat bahan yang berada di lingkungan sebagai sumber belajar. Permainan media dakon meningkatkan kemampuan berhitung karena permainan ini anak memainkannya dengan berhitung, secara tidak langsung anak mengenal penjumlahan, anak mengenal konsep bilangan, anak juga mengenal jumlah bilangan. Maka dengan ini permainan media dakon mampu meningkatkan perkembangan kognitif anak, atau kemampuan berhitung anak.

\section{SIMPULAN DAN SARAN}

Berdasarkan penelitian yang telah dilakukan tentang pengembangan media permainan dakon untuk perkembangan berhitung anak. Media permainan dakon untuk perkembangan behitung anak yang lebih dikenal dengan congklak. Media permainan dakon terdiri dari 12 lubang dengan 2 lubang induk dan 10 anak lubang dengan bentuk ikan. Media permainan dakon untuk perkembangan berhitung anak dapat meningkat kemampuan berhitung anak pada anak usia 4-5 tahun di TK AL-HIDAYAH. Peningkatan hasil perkembangan kemampuan berhitung anak dengan menggunakan media permainan dakon meningkat sehingga artinya terdapat perbedaan secara signifikan antara hasil belajar kemampuan berhitung sebelum menggunakan media permainan dakon dan sesudah menggunakan permainan dakon, sehingga permainan dakon dapat digunakan sebagai media pembelajaran. Berdasarkan hasil penelitian yang telah dilakukan bahwa media dakon berhasil dikembangkan untuk meningkatkan kemampuan berhitung anak, maka peneliti berharap selanjutkan akan ada penelitian yang kembali mengembangkan produk yang mampu meningkatkan kemampuan perkembangan anak.

\section{DAFTAR PUSTAKA}

Dewi, Ajeng Rahayu Tresna dkk. (2019). Kemampuan mengenal lambang bilangan melalui media kartu angka, Jurnal Pelita PAUD, 3 (1), 46-57

Cahyati, Nika. (2018). Kemampuan mengenal angka melalui media memancing bola angka, Jurnal Pelita PAUD, 2 (2), 200-213

Amanda, Dinda Dwi. (2013). Meningkatkan kemampuan berhitung anak usia dini melalui permainan book scvenger hunt. Serang: Upi.Edu. 2013, Universitas Pendidikan Indonesia. Skripsi.

Cahyati, N. (2018). KEMAMPUAN MENGENAL ANGKA MELALUI MEDIA

MEMANCING. Jurnal Pelita PAUD, 2(2), 200-213.

Haerudin, D. A. . N. C. (2018). PENERAPAN METODE STORYTELLING BERBASIS CERITA RAKYAT DALAM MENANAMKAN NILAI-NILAI KARAKTER ANAK. Jurnal Pelita PAUD, 3(1), 1-9. https://doi.org/https://doi.org/10.33222/pelitapaud.v3i1.420

Horunisa, P. S., \& Cahyati, N. (2020). Media Permainan Sunda Manda Robot Bercahaya Untuk Kemampuan Keseimbangan Anak. 04(1), 1-11. 
Prima Nataliya. (2011). Efektivitas Penggunaan Media Pembelajaran Permainan Tradisional Congklak Untuk Meningkatkan Kemampuan Berhitung Pada Siswa Sekolah Dasar. Ilmiah Psikologi Terapan, 03(02), 343-358.

Putri Sarasati, T., \& Cahyati, N. (2020). Pengembangan Boneka Edukatif untuk Pengenalan Pendidikan Seks Anak. Jambura Early Childhood Education Journal, 2(2), 58-69. https://doi.org/10.37411/jecej.v2i2.152

Uniati, T. (2019). Penerapan Permainan Dakon Sebagai Upaya untuk Meningkatkan Pemahaman Konsep Penambahan dan Pengurangan Pada Anak TK Kelompok B. 1(2), $132-140$.

Verdawati, E. (2013). Penerapan Media Permainan Dakon Dalam Peningkatan Hasil Belajar Berhitung Siswa Kelas 1 Sd Al-Amin Surabaya. Jurnal Penelitian Pendidikan Guru Sekolah Dasar, 1(1), 1-7.

Wijaya Kuswanto, C., \& Dinda Pratiwi, D. (2020). Pengembangan Bahan Ajar Pendidikan Jasmani untuk Anak Usia Dini Berbasis Tematik. Al-Athfal : Jurnal Pendidikan Anak, 6(1), 55-68. https://doi.org/10.14421/al-athfal.2020.61-05

Yenti, L. S. (2015). Pembuatan Permainan Dakon Virtual. Jurnal Ilmiah Mahasiswa Universitas Surabaya, 4(1), 1-13.

Khairi, Husnuzziadatul. (2018). Karakteristik perkembangan anak usia dini dari 0-6 tahun. Jurnal Warna, 2 (1), 17-18

Fauziyah Putri Ratna, dkk. (2017). Kemampuan berhitung permulaan melalui metode demontrasi dengan media sempoa pada anak kelompok B1 di TK amelia kecamatan sumbersari kabupaten jember tahun pelajran 2016/2017. Jurnal Edukasi, 4 (3), 45-48

Rahman, Ulfiana. (2009). Karakteristik perkembangan anak usia dini. Jurnal Lentara Pendidikan, 12 (1), 45-57

Romlah, Medinda, dkk.(2016). Peningkatan kemampuan berhitung anak melalui kegiatan bermain sempoa. Jurnal Ilmiah Potensia, 1 (2), $72-73$

Utami, Tri. (2017). Penanaman kompetensi inti melalui pendekatan saintifik di PAUD an-nuur. Jurnal Pendidikan Anak Usia Dini, 1 (2), 92-93

Yeni. (2016). Pengaruh Permainan Tradisional Congklak Terhadap Kemampuan Berhitung Permulaan Anak Usia Dini 4-5 Tahun. Serang: Upi. Edu. 2016, Universitas Pendidikan Indonesia. Skripsi

Ismatul Khasanah, dkk. (2014). Permainan tradisional sebagai media stimulasi aspek perkembangan anak usia dini. Jurnal Penelitian, 1(1), 91-105

Saribu, Putri Budiani Dolok, dkk. (2018). Pengaruh permainan tradisional congklak terhadap kemampuan berhitung anak permulaan anak usia 4-5 tahun di KB Tunas Harapan Kecamatan Sunggal Kab. Deli Serang. Jurnal Usia Dini, 4 (1), 28-38

Mufarizudin, Moh Faizuddin. (2018). Useful of clap hand games for optimalize cogtivite aspects in early childhood education. Jurnal Obsesi, 2 (2), 162-169

Cahyati, N. (2018). KEMAMPUAN MENGENAL ANGKA MELALUI MEDIA

MEMANCING. Jurnal Pelita PAUD, 2(2), 200-213.

Haerudin, D. A. . N. C. (2018). PENERAPAN METODE STORYTELLING BERBASIS CERITA RAKYAT DALAM MENANAMKAN NILAI-NILAI KARAKTER ANAK. Jurnal Pelita PAUD, 3(1), 1-9.

https://doi.org/https://doi.org/10.33222/pelitapaud.v3i1.420

Horunisa, P. S., \& Cahyati, N. (2020). Media Permainan Sunda Manda Robot Bercahaya Untuk Kemampuan Keseimbangan Anak. 04(1), 1-11.

Prima Nataliya. (2011). Efektivitas Penggunaan Media Pembelajaran Permainan Tradisional Congklak Untuk Meningkatkan Kemampuan Berhitung Pada Siswa Sekolah Dasar. 
Ilmiah Psikologi Terapan, 03(02), 343-358.

Putri Sarasati, T., \& Cahyati, N. (2020). Pengembangan Boneka Edukatif untuk Pengenalan Pendidikan Seks Anak. Jambura Early Childhood Education Journal, 2(2), 58-69. https://doi.org/10.37411/jecej.v2i2.152

Uniati, T. (2019). Penerapan Permainan Dakon Sebagai Upaya untuk Meningkatkan Pemahaman Konsep Penambahan dan Pengurangan Pada Anak TK Kelompok B. 1(2), $132-140$.

Verdawati, E. (2013). Penerapan Media Permainan Dakon Dalam Peningkatan Hasil Belajar Berhitung Siswa Kelas 1 Sd Al-Amin Surabaya. Jurnal Penelitian Pendidikan Guru Sekolah Dasar, 1(1), 1-7.

Wijaya Kuswanto, C., \& Dinda Pratiwi, D. (2020). Pengembangan Bahan Ajar Pendidikan Jasmani untuk Anak Usia Dini Berbasis Tematik. Al-Athfal : Jurnal Pendidikan Anak, 6(1), 55-68. https://doi.org/10.14421/al-athfal.2020.61-05

Yenti, L. S. (2015). Pembuatan Permainan Dakon Virtual. Jurnal Ilmiah Mahasiswa Universitas Surabaya, 4(1), 1-13. 